INTERNATIONAL JOURNAL OF RESEARCHES IN BIOSCIENCES, AGRICULTURE AND TECHNOLOGY (C) VISHWASHANTI MULTIPURPOSE SOCIETY (Global Peace Multipurpose Society) R. No. MH-659/13(N) www.vmsindia.org

\title{
INVESTIGATION ON METALS ACCUMULATION AND TRANSLOCATION OF TRACE METALS IN VEGETABLE CROPS GROWN ON IRRIGATED SOIL ALONG THE BANK OF NAG RIVER NAGPUR (MH), INDIA
}

\author{
A. S. Mahakalkar ${ }^{1}$, R.R.Gupta ${ }^{2}$ and S.V. Kulkarni1 \\ ${ }_{1}^{1}$ Sevadal Mahila Mahavidyalaya, Sakkaradara Square, Nagpur-009 \\ ${ }^{2}$ Mohata Science college, Sakkaradara Square, Nagpur-009 \\ anjaliml@rediffmail.com
}

\begin{abstract}
:
Assessment of metal-contaminated soils depends on how one can predict the bioavailability of trace and toxic metals in soil and transfer to the human food chain. To predict the uptake of $\mathrm{Cu}, \mathrm{Mn}$, Fe and $\mathrm{Zn}$ by Leafy vegetables grown on agricultural soil on the bank of Nag river, 20 vegetables and 5 soil samples were collected from areas irrigated with wastewater as study samples and for comparative purposes, agricultural soil samples irrigated with fresh river water, was collected as control samples. The samples were analyzed by atomic absorption spectrophotometer. The level of $\mathrm{Cu}$ ranged from 0.4- 0.44 $\mathrm{mg} / \mathrm{g}$ Mn from 0.67-0.71 mg/g, Fe from $11.06-11.09$ $\mathrm{mg} / \mathrm{g}$ and $\mathrm{Zn}$ from 2.82-2.88 mg/g Dry Weights (DW) for soil samples. The average concentration of these heavy metals in Brinjal was 0.002, 0.003, 1.99 and 1.208, in Flower it was 0.002, 0.0034, 2.095 and 1.014, in Bathua it was $0.002,0.0026,2.032,1.428$, in Chawli it was 0.0022, 0.0026, 2.63, 0.838, in Spinach it was 0.0022, 0.0024, $2.056,1.328 \mathrm{mg} / \mathrm{g}$ for $\mathrm{Cu}, \mathrm{Mn}, \mathrm{Fe}$ and $\mathrm{Zn}$ metals respectively. Metal transfer factors from soil to vegetable are found more significant for Fe followed by $\mathrm{Zn}$ and very less for $\mathrm{Cu}$ and $\mathrm{Mn}$.
\end{abstract}

Keywords: Heavy metals, Nag River, Nagpur

\section{Introduction:}

Soil contamination by heavy metals due to anthropogenic activities has remained a great problem all over the world especially in developing countries. Anthropogenic activities as agricultural processes, industrialization and domestic activities have caused the increase of heavy metals in soils and plants grown on such soils. The processes could also affect surface and ground water.

The main sources of heavy metals to vegetable crops are their growth media (soil, air, nutrient solutions) from which these are taken up by the roots or foliage. Vegetables constitute essential diet components by contributing protein, vitamins, iron, calcium and other nutrients, which are usually in short, supply Thompson and Kelly, 1990 [1]. They also act as buffering agents for acidic substances produced during the digestion process. However, they contain both essential and toxic elements over a wide range of concentrations. Metal accumulation in vegetables may pose a direct threat to human health Türkdogan et al., 2003 [2]. Vegetables take up metals by absorbing them from contaminated soils, as well as from deposits on different parts of the vegetables exposed to the air from polluted environments Zurera-Cosano et al., 1989 [3].

Vegetables mostly grown by irrigation are Brinjal, Cauliflower, Bathua, Chawli and Spinach. The aim of this work is to determine the content of toxic metals in soil and vegetables from a suspected contaminated site of irrigated farmlands around Nag River in Nagpur City.

\section{Material and Methods: Reagents and Glasswares}

All the chemicals used for this work were of analytical grades obtained from Central Scientific Nagpur. Deionised water was used throughout the work. All glass wares used were soaked in 20\% HNO3 over night and then washed with detergent, thoroughly rinsed with tap water and then with deionised water.

\section{Sampling Sites}

The research was carried out on soil and vegetable samples collected from irrigated farmlands around Nag River, Nagpur. The samples were collected from farm sites/locations in Bharatwada, Pawangaon, Asoli, Mahalgaon and Dighori area.

\section{Sample Collection}

Soil and vegetable sampling process was random; at each sampling point four (4) subsamples from the top layer were collected at a depth of $0-20 \mathrm{~cm}$ and $20 \mathrm{~m}$ apart using a stainless steel auger. The collected sub-samples were then pooled together to form a composite of each individual sample. The soil and vegetable samples were collected from above five areas with a source of water close to the farmland. Control samples were also collected from a less suspected contaminated soil and these gave five samples altogether. The vegetables available at the time of sampling were Brinjal, Cauliflower, Bathua, Chawli and Spinach. The samples were collected in clean polythene bags and transported to the laboratory for further processing. 


\section{Sample Pre-Treatment}

The different soil samples were air-dried in the laboratory for a week, after which it was pulverized and passed through a $2.0-\mathrm{mm}$ sieve (this is for $\mathrm{pH}$ and Total Metal) while for Organic Matter, some portion of the individual sieved soil samples were further pulverized to fine powder and passed through $0.5-\mathrm{mm}$ sieve. The Brinjal, Cauliflower, Bathua, Chawli and Spinach samples were cut into nearly uniform sizes. This was done to facilitate drying of the pieces at the same rate. The cut pieces were placed in clean acid-washed porcelain crucibles according to label and oven-dried at $105^{\circ} \mathrm{C}$ for 24 hours in an oven until they were brittle and crispy. At this stage no micro-organisms can grow on it. All crucibles were labeled according to sample numbers. The dried vegetable samples were grounded into fine particles using washed porcelain mortar and pestle. The powdered samples were placed in labeled Petri dishes and dried to constant weight in desiccators until they were digested.

\section{Soil Properties}

Some properties of the soil samples investigated were determined using standard methods. Soil $\mathrm{pH}$ was determined using deionized water in the ratio 1:1 (soil: water) suspension according to Tan 1996 [4], percentage organic matter was determined by Walkley-Black titration method [5].

\section{Digestion of Samples \\ Soil samples}

One gram (1g) of the air- dried ground soil samples was mixed with $20 \mathrm{~cm} 3(1: 1) \mathrm{HCl} /$ HNO3 acid mixtures and the content was heated on a hot plate until dryness. The residue was dissolved using $2 \mathrm{M} \mathrm{HCl}$ and filtered into $50 \mathrm{~cm} 3$ volumetric flask for metal analysis. A Unicam Atomic Absorption Spectrophotometer (AAS) equipped with an air acetylene burner was used to determine the metal contents. The acid mixture was adopted according to Abulude 2005. Duplicate samples were prepared and a blank was incorporated into a batch of every 5 duplicate samples.

\section{Vegetable samples}

A slightly modified procedure according to Awofolu 2005 [6] was used for digestion of the vegetable samples. $0.5 \mathrm{~g}$ of sieved leaf samples were weighed into $100 \mathrm{ml}$ beaker. A mixture of $7 \mathrm{ml}$ concentrated trioxonitrate (IV) acid and $4 \mathrm{ml}$ of $70 \%$ perchloric acid was added and this was digested at low heat using hot plate until near dryness. The digest was allowed to cool, filtered into $50 \mathrm{ml}$ standard flask using Whatman (110) filter paper and made up to the mark with $5 \mathrm{M}$
HNO3. Duplicate digestion of each sample was carried out together with a blank digest which was incorporated in every batch of 5 duplicate samples. The blank was prepared using the same procedure as above with an exception of the samples.

Analysis

Appropriate working standards were prepared for each of the metal solution by serial dilution of the stock solutions. Each of the sets of serial dilutions was then aspirated one after the other into the Atomic Absorption Spectrometry and their absorbance recorded. The sample solutions were also aspirated one after the other and the absorbance recorded. Calibration curves were plotted for each of the trace metals standard using absorbance against concentrations (ppm) and the actual concentration of the metal interpolated from the curves.

\section{Results and Discussions:}

Similarly table 2 shows the detailed concentration of $\mathrm{Cu}, \mathrm{Mn}, \mathrm{Fe}$ and $\mathrm{Zn}$ in different vegetables. In Brinjal it was 0.002, 0.003, 1.99 and 1.208, in Cauliflower 0.002, 0.0034, 2.095 and 1.014, in Bathua 0.002, 0.0026, 2.032, 1.428 , in Chawli 0.0022, 0.0026, 2.63, 0.838 and in Spinach it was 0.0022, 0.0024, 2.056, $1.328 \mathrm{mg} / \mathrm{g}$.

Transfer factors for heavy metals: Table 3 show the Transfer Factor (TF) of $\mathrm{Cu}, \mathrm{Mn}, \mathrm{Fe}$ and $\mathrm{Zn}$ from soil to plant, which is one of the key components of human exposure to metals through the food chain. Transfer factors were determined to quantify the relative difference in bioavailability of metals to plants or to identify efficiency of plant species to accumulate a given metal. These factors were based on the root uptaken of metals and discount the foliar absorption of atmospheric metal deposits. The degree of accumulation shows that $\mathrm{Zn}$ is higher than Fe.

Table 1 show that concentration of $\mathrm{Cu}$ ranged from 0.4- $0.44 \mathrm{mg} / \mathrm{g} \mathrm{Mn}$ from 0.67 $0.71 \mathrm{mg} / \mathrm{g}, \mathrm{Fe}$ from $11.06-11.09 \mathrm{mg} / \mathrm{g}$ and $\mathrm{Zn}$ from $2.82-2.88 \mathrm{mg} / \mathrm{g}$ Dry Weights (DW) for soil samples. The concentration levels of these heavy metals in the soil are higher than the recommended value by FAO/WHO 2001 [7] i.e. conc. Of $\mathrm{Cu}$ was higher than $0.270 \mathrm{mg} / \mathrm{g}$, conc. of $\mathrm{Zn}$ was much higher than $0.600 \mathrm{mg} / \mathrm{g}$. 
Table1: Total metal contents (mg/g) and soil properties of Nag River irrigated farmlands

\begin{tabular}{|l|l|l|l|l|}
\hline Sites & $\mathrm{Cu}$ & $\mathrm{Mn}$ & $\mathrm{Fe}$ & $\mathrm{Zn}$ \\
\hline 1 & 0.42 & 0.69 & 11.08 & 2.85 \\
\hline 2 & 0.4 & 0.67 & 11.09 & 2.86 \\
\hline 3 & 0.43 & 0.68 & 11.09 & 2.88 \\
\hline 4 & 0.44 & 0.7 & 11.06 & 2.84 \\
\hline 5 & 0.41 & 0.71 & 11.08 & 2.82 \\
\hline Min & 0.4 & 0.67 & 11.06 & 2.82 \\
\hline Max & 0.44 & 0.71 & 11.09 & 2.88 \\
\hline Ave & 0.42 & 0.69 & 11.08 & 2.85 \\
\hline
\end{tabular}

Table 2: Total Metal Contents (mg/g) in Vegetables of Irrigated Farmland around Nag River

\begin{tabular}{|l|l|l|l|l|l|}
\hline Sites & Vegtables & $\mathrm{Cu}$ & $\mathrm{Mn}$ & $\mathrm{Fe}$ & $\mathrm{Zn}$ \\
\hline & Brinjal & 0.002 & 0.005 & 2.35 & 1.06 \\
\hline & Flower & 0.002 & 0.004 & 2.21 & 1.1 \\
\hline Site-I & Bathua & 0.001 & 0.002 & 1.68 & 1.69 \\
\hline & Chawli & 0.003 & 0.001 & 2.63 & 0.83 \\
\hline & Spinach & 0.002 & 0.004 & 2.43 & 1.52 \\
\hline & Brinjal & 0.001 & 0.002 & 1.93 & 0.98 \\
\hline & Flower & 0.001 & 0.003 & 2.43 & 1.15 \\
\hline Site-II & Bathua & 0.002 & 0.002 & 2.22 & 1.1 \\
\hline & Chawli & 0.003 & 0.002 & 2.65 & 0.86 \\
\hline & Spinach & 0.003 & 0.001 & 1.2 & 1.04 \\
\hline & Brinjal & 0.002 & 0.004 & 1.34 & 1.46 \\
\hline & Flower & 0.001 & 0.002 & 2.52 & 0.65 \\
\hline Site-III & Bathua & 0.004 & 0.003 & 2.37 & 1.88 \\
\hline & Chawli & 0.002 & 0.003 & 2.64 & 0.83 \\
\hline & Spinach & 0.001 & 0.002 & 2.44 & 1.36 \\
\hline & Brinjal & 0.002 & 0.001 & 3.04 & 1.11 \\
\hline & Flower & 0.003 & 0.002 & 1.95 & 1.24 \\
\hline Site-IV & Bathua & 0.004 & 0.003 & 2.07 & 1.04 \\
\hline & Chawli & 0.002 & 0.004 & 2.63 & 0.82 \\
\hline & Spinach & 0.002 & 0.003 & 2.43 & 1.46 \\
\hline & Brinjal & 0.003 & 0.003 & 1.34 & 1.43 \\
\hline & Flower & 0.003 & 0.006 & 1.36 & 0.93 \\
\hline Site-V & Bathua & 0.001 & 0.003 & 1.82 & 1.43 \\
\hline & Chawli & 0.001 & 0.003 & 2.67 & 0.85 \\
\hline & Spinach & 0.003 & 0.002 & 1.78 & 1.26 \\
\hline & Brinjal & 0.002 & 0.003 & 1.99 & 1.208 \\
\hline & Flower & 0.002 & 0.0034 & 2.095 & 1.014 \\
\hline Average & Bathua & 0.002 & 0.0026 & 2.032 & 1.428 \\
\hline & Chawli & 0.0022 & 0.0026 & 2.63 & 0.838 \\
\hline & Spinach & 0.0022 & 0.0024 & 2.056 & 1.328 \\
\hline & & & & & \\
\hline
\end{tabular}

Table 3: Soil-plant Transfer factor (TF) of vegetables

\begin{tabular}{|l|l|l|l|l|}
\hline Veg. & $\mathrm{TF}_{\mathrm{Cu}}$ & $\mathrm{TF}_{\mathrm{Mn}}$ & $\mathrm{TF}_{\mathrm{Fe}}$ & $\mathrm{TF}_{\mathrm{Zn}}$ \\
\hline Brinjal & 0.0048 & 0.0043 & 0.179 & 0.358 \\
\hline Flower & 0.0048 & 0.0049 & 0.189 & 0.356 \\
\hline Bathua & 0.0048 & 0.0038 & 0.183 & 0.501 \\
\hline Chawli & 0.0052 & 0.0038 & 0.237 & 0.294 \\
\hline Spinach & 0.0052 & 0.0035 & 0.185 & 0.466 \\
\hline
\end{tabular}

\section{Conclusion:}

The results indicate that the soil had slightly high levels of $\mathrm{Cu}$ and $\mathrm{Mn}$ while the levels of soil $\mathrm{Fe}$ and $\mathrm{Zn}$ are much higher than the tolerable levels. For vegetables (exposed)

however relatively high levels of the trace metals were also observed. The metal levels were close to the toxic levels for $\mathrm{Fe}$ and $\mathrm{Zn}$ in plants recommended by the Food and Agricultural Organization (FAO) and the WHO/EU joint limits. The high levels of these toxic metals in vegetables could be ascribed to deposits from vehicle emission and probably from the Nag water use for irrigation where waste water of all kinds is released. This put the consumers of these and other vegetable crop grown within this farmland at health risk with time and as such continues monitoring of this farmland and the water used for irrigation is needed.

\section{References:}

1. H.C. Thompson, and W.C. Kelly, Vegetable Crops. Delhi: Mac Graw Hill Publishing Company Ltd. Pp.5, 1990

2. M.K. Turkdogan, F. Kilicel, I. Tuncer, and I. Uygan, Heavy Metals in Vegetables and Fruits in the Endemic Upper Gastrointestinal Cancer Region of Turkey. Environmental Toxicoloy Phamacology. 13, pp. 175-179, 2003

3. Zurera-Cosano, G., Moreno-Rojas, R., Salmeron-Egea, J. and Pozo Lora, R. 1989. Heavy Metal Uptake from Greenhouse Border Soils for Edible Vegetables. Journal of Science and Food Agriculture. 49(3), pp. 307-314

4. K.M. Tan, Soil Sampling Preparation and Analysis. (Mercel Dekkes. Inc: New York. Basel. Hong Kong), 1996

5. A. Walkley, and I. A. Black, An Examination of the Detjare Method for Determining Soil Organic Matter

6. O.R. Awofolu, A survey of Trace Metals in Vegetable, Soil and Lower Animal along some Selected Major Roads in Metropolitan City of Lagos. Environmental Monitoring and Assessment. 105, pp. 431-447, 2005

7. FAO/WHO, Food Additives and Contaminants. Joint FAO/WHO Food Standards Programme, ALINORM 01/12A. pp.1-289, 2001 